\title{
Anesthesia assistants in Canada
}

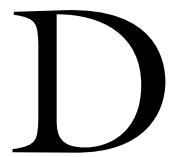

ELIVERY of anesthetic care in Canada has focused primarily on the role of the attending anesthesiologist, a physician with specialty training recognized by the Royal College of Physicians and Surgeons of Canada. The knowledge, skills and attributes required of specialist anesthesiologists have been well taught in Canadian University Departments of Anesthesia. Canadian anesthesiologists have participated in and actively promoted research in their specialty and have worked extensively, both nationally and internationally, to ensure that the highest quality of anesthetic care is delivered to patients. Over the years, anesthesiologists in Canada have relied on the service of allied health providers to assist them in the delivery of anesthetic care. The "anesthesia assistant" has emerged in health care institutions providing anesthetic services. Some institutions have job descriptions and designated individuals who assist anesthesiologists; other institutions use allied health providers who, in addition to other responsibilities, assist in the anesthetic care of patients. The role of the anesthesia assistant has developed informally across Canada, rather than through formalized regional or national processes. A major exception is the province of Quebec where provincial legislation defines the responsibilities of anesthesia assistants. ${ }^{1}$

The letter by du Boulay and Nixon in this issue describes the role and value of anesthesia assistants in the United Kingdom. They write that "the Association of Anaesthetists of Great Britain and Ireland (AAGBI) has made a number of recommendations on anaesthetic assistance". In the letter du Boulay and Nixon indicate their surprise that Canadian anesthesiologists often work without anesthesia assistants.

The Canadian Anesthesiologists' Society (CAS), like the AAGBI, has examined the role of anesthesia assistants in the delivery of anesthetic care in Canada. The CAS supports the model of the anesthetic care team, where anesthesia assistants work under the supervision of the attending anesthesiologist and CAS
Guidelines to the Practice of Anesthesia are followed. The CAS, on behalf of anesthesiologists in Canada, has worked to formalize the role of anesthetic assistants in the delivery of anesthetic care in Canada.

In June 1993 the CAS formed a multi disciplinary task force, the Task Force on Anesthesia Assistants, to examine the role of assistants in the provision of anesthesia services in Canada. Under the chairmanship of Dr. John Atkinson, the Task Force included anesthesiologists, respiratory therapists, operating room nurses and an anesthesia technician. The final report of the Task Force, presented to the CAS Council in June 1995 , concluded there is a place for assistants in the delivery of anesthetic services. ${ }^{2}$ The Task Force recognized the expanding nature of anesthesia services inside and outside the operating room and the need for anesthesiologists to have assistance, similar to that required by surgeons in an operating room. The Task Force concluded that the anesthesiologist would retain the final responsibility for patient care and that the anesthesiologist and the anesthesia assistant would work as a team to provide the best patient care. The Task Force recommended that existing programs for anesthesia assistants be built upon and a unique challenge exam be established to assess the level of skill of anesthesia assistants. Membership for anesthesia assistants within the CAS was also recommended. The final report of the Task Force was approved by the CAS Council in June 1995.

Subsequently, the CAS, in collaboration with the Canadian Society of Respiratory Therapists and the Operating Room Nurses Association of Canada, submitted to Human Resources and Development Canada (HRDC) a proposal for the development of a national task analysis and competency profile for anesthesia assistants in Canada. ${ }^{3}$ At that time, the federal government was providing funding for the development of national competency profiles through its sectoral partnerships initiative. The proposal to HRDC included a broad based consortium of national and provincial stakeholders with an interest in the delivery

Address correspondence to: Dr. Linda Nugent, Medical Director, Anesthesia Program, Winnipeg Regional Health Authority, 300 Booth Drive, Winnipeg, Manitoba R3J 3M7 E-mail: elambkin@ggh.mb.ca 
of anesthetic care in Canada to oversee the project. The initial work on describing the current tasks performed by anesthesia assistants in Canada was to be done by a focus group comprised of anesthesiologists and anesthesia assistants under the direction of a consultant hired for the project. From the task analysis, the focus group and consultant were to develop a draft national competency profile for anesthesia assistants. The draft profile was to be validated through mail survey to large numbers of anesthesiologists, respiratory therapists and operating room nurses in Canada. The outcome of the project was to be a validated Canadian competency profile for anesthesia assistants written in both official languages.

Because the proposal for the development of a national competency profile for anesthesia assistants was a health sector project, Human Resources Development Canada required the approval of all provinces and territories of the Federal/Provincial/Territorial Advisory Committee on Health Human Resources (ACHHR). In June 1997, the ACHHR decided not to support funding of the project for three reasons. ${ }^{4}$ The first reason was that the need to recognize a new category of health care provider in regard to the provision of anesthesia services was not identified or supported in ACHHR discussions with employers and regulators. The second reason was that jurisdictions did not identify patient safety or competency concerns with respect to the professionals currently providing anesthesia services. The third reason was that the proposal did not meet criteria associated with ensuring appropriate representation from regulatory bodies, employers and appropriate provincial/territorial ministries.

It was apparent from the ACHHR decision that discussions needed to occur directly between the individuals responsible for national and provincial health human resource planning and the anesthesiologists providing anesthetic care in Canada. It was important that the concept of anesthetic care teams was understood and supported. It was also important that there was support for initiatives that could achieve the required number of anesthesiologists to direct anesthetic care teams. The issue of resource planning for anesthesiologists in Canada is a significant issue and has been the subject of recent articles in the Canadian Journal of Anesthesia. ${ }^{5,6}$

In 1999 the CAS Board established the Ad Hoc Committee on Physician Resources to identify strategies that could deal with the current shortage of anesthesiologists in Canada and ensure future planning of physician resources in anesthesia. In its liaison with national and provincial stakeholders, the Committee is also discussing the model of anesthetic care teams. The CAS, through its Committee on Physician Resources, is hoping that both aspects of anesthetic delivery will be achieved in Canada.

It is no small undertaking to build a consensus among national and provincial stakeholders on a Canadian model for the delivery of anesthetic care. Once achieved, it will be possible to develop and validate a national competency profile for anesthesia assistants. The profile will then guide curriculum development for anesthesia assistant training programs, with curriculum development conceivably by one or more Canadian University Departments of Anesthesia. Future training programs for anesthesia assistants will need to consider methods for prior learning assessment because it is likely that allied health providers entering training programs will already have attained some of the competencies through previous education in respiratory therapy, nursing or international medical schools. Accreditation of training programs in many allied health disciplines occurs through the Canadian Medical Association Conjoint Accreditation process. ${ }^{7}$ The CAS is a national accreditation sponsor of Conjoint Accreditation and accreditation through this process would be a great benefit to educational programs for anesthesia assistants.

Recognition of graduates of accredited training programs with the credentials of an anesthesia assistant will need to occur. In Manitoba, a recent amendment to the Medical Act has created the capability to licence clinical assistants such as anesthesia assistants through the College of Physicians and Surgeons. A constant common feature for all clinical assistants licenced by the College of Physicians and Surgeons of Manitoba is the existence of a supervising physician. Clinical assistants who successfully meet the College requirements are entitled to use the designation "Registered Clinical Assistant" ("RCA"). Other jurisdictions, such as the Ordre professionnel des inhalothérapentes du Québec (OPIQ) and the CSRT, also recognize and designate graduates of respiratory therapy programmes with additional training in anesthesia.

In recognition of allied health providers who are anesthesia assistants within health care institutions, the Board of the CAS recently approved a new CAS membership category for anesthesia assistants. The motion of the Board, which requires ratification by the CAS membership, indicates the importance of anesthesia assistants to anesthesiologists in Canada.

There is much work ahead before the role of anesthesia assistants is formalized in Canada. However, the opportunity for Canadian anesthesiologists to create an uniquely Canadian model of anesthetic service delivery is very exciting. 


\section{Les assistants en}

\section{anesthésie au Canada}

Au Canada, on a principalement centré l'attention sur les soins anesthésiques rendus par l'anesthésiologiste traitant, un médecin qui a une formation spécialisée reconnue par le Collège royal des médecins et chirurgiens du Canada. Les connaissances, habiletés et attributs nécessaires aux anesthésiologistes spécialisés ont été bien enseignés dans les départements d'anesthésie des universités canadiennes. Ces anesthésiologistes ont pris part à la recherche dans leur spécialité et l'ont activement promue. Ils ont beaucoup travaillé, autant au pays qu'à l'étranger, pour que des soins de grande qualité soient donnés aux patients. Au cours des années, les anesthésiologistes du Canada ont pu compter sur des auxiliaires qui les ont aidé à rendre des soins anesthésiques. «L'assistant en anesthésie» est ainsi apparu dans les institutions de santé. Certaines institutions ont des descriptions de tâches et des personnes désignées pour assister les anesthésiologistes; d'autres utilisent des auxiliaires médicaux qui, entre autres responsabilités, secondent les anesthésiologistes. Le rôle de l'assistant en anesthésie a évolué de façon informelle à travers le Canada plutôt que par un processus formel régional ou national. La province de Québec constitue une exception importante : une loi provinciale définit les responsabilités des assistants en anesthésie. ${ }^{1}$

La lettre de du Boulay et Nixon, dans le présent numéro, décrit le rôle et la valeur des assistants en anesthésie au Royaume-Uni. Ils écrivent que l'«Association of Anaesthetists of Great Britain and Ireland (AAGBI) a produit nombre de recommandations sur l'assistance anesthésique». La lettre fait état de leur surprise de découvrir que les anesthésiologistes canadiens travaillent souvent sans assistants.

La Société canadienne des anesthésiologistes (SCA), comme l'AAGBI, a étudié le rôle des assistants en anesthésie au Canada. La SCA encourage le modèle d'équipe anesthésique, où l'assistant travaille sous la supervision de l'anesthésiologiste et où sont suivies les Recommandations de la SCA sur la pratique en anesthésie. La SCA, au nom des anesthésiologistes du Canada, a travaillé à formuler le rôle des assistants anesthésiques.

En juin 1993, la SCA a formé une équipe de travail multidisciplinaire, la Task Force on Anesthesia Assistants (Groupe de travail sur les assistants en anesthésie), pour étudier le rôle des assistants en anesthésie. Sous la présidence du docteur John Atkinson, le groupe comprenait des anesthésiologistes, des inhalothérapeutes, du personnel infirmier de la salle d'opération et un technicien en anesthésie. Le rapport final du groupe, présenté au Conseil de la SCA en juin 1995, concluait qu'il y avait une place pour les assistants en anesthésie. ${ }^{2}$ Le groupe a reconnu l'étendue croissante des services à rendre en anesthésie à l'intérieur comme à l'extérieur de la salle d'opération et le besoin d'assistance semblable à celui des chirurgiens dans la salle d'opération. L'équipe de travail a conclu que l'anesthésiologiste devait demeurer le principal responsable des soins au patient et qu'il travaillerait en équipe avec son assistant dans le but de fournir les meilleurs soins. On a recommandé que les programmes déjà existants pour les assistants en anesthésie soient utilisés et qu'un unique examen soit établi pour évaluer le niveau de compétence des assistants. La participation des assistants à la SCA a aussi été recommandée. Le rapport final du groupe a été approuvé par le Conseil de la SCA en juin 1995.

Par la suite, la SCA, en collaboration avec la Société canadienne des inhalothérapeutes et l'Association des infirmières en salle d'opération du Canada, a soumi à Développement des ressources humaines Canada (DRHC) la proposition de l'élaboration d'une analyse de tâche nationale et de profil de compétence pour les assistants en anesthésie au pays. ${ }^{3}$ À cette époque, le gouvernement fédéral accordait du financement pour le développement de profils de compétence nationaux par l'intermédiaire des associations sectorielles. La proposition de DRHC comportait une importante association de base, des participants nationaux et provinciaux intéressés aux soins anesthésiques au Canada, pour superviser le projet. Le travail initial de description des tâches courantes réalisées par les assistants en anesthésie au Canada a été fait par un groupe d'intérêt réunissant des anesthésiologistes et des assistants en anesthésie sous la direction d'un consultant engagé pour le projet. À partir de l'analyse des tâches, le groupe et le consultant devaient élaborer l'ébauche d'un profil de compétence national pour les assistants en anesthésie. Ce profil devait être validé au moyen d'une enquête envoyée par la poste à un grand nombre d'anesthésiologistes, d'inhalothérapeutes et d'infirmières de salle d'opération à travers le Canada. Le résultat du projet devait être un profil de compétence canadien pour les assistants en anesthésie, rédigé dans les deux langues officielles.

Comme la proposition portant sur l'élaboration d'un profil de compétence national pour les assistants en anesthésie était un projet du secteur de la santé, 
Développement des ressources humaines Canada devait obtenir l'accord du Comité consultatif fédéral, provincial et territorial sur les Ressources humaines du secteur de la santé (CCRHS) des provinces et des territoires. En juin 1997, le CCRHS a décidé de ne pas appuyer le projet pour trois raisons. ${ }^{4}$ La première était que la nécessité de reconnaître une nouvelle catégorie de dispensateur de soins de santé dans le but de fournir des services en anesthésie n'a pas été reconnue ou soutenue lors des discussions du CCRHS avec les employeurs et les administrateurs. La deuxième raison relevait du fait que les juridictions n'ont pas identifié les aspects touchant la sécurité ou la compétence en regard des professionnels qui fournissent actuellement des services en anesthésie. La troisième voulait que la proposition ne rencontre pas les critères de représentation appropriée des organismes de régulation, employeurs et ministères provinciaux et territoriaux.

Il était clair que les discussions devaient avoir lieu directement entre les personnes responsables de la planification nationale et provinciale des ressources humaines dans le secteur de la santé et les anesthésiologistes du Canada. Il était important que le concept d'équipe de soins anesthésiques soit compris et appuyé. Il était aussi important qu'il y ait un soutien des initiatives visant à obtenir le nombre nécessaire d'anesthésiologistes pour diriger les équipes de soins anesthésiques. La question de la planification des ressources est essentielle pour les anesthésiologistes canadiens et a fait l'objet de récents articles dans le Journal canadien d'anesthésie. ${ }^{5,6}$

En 1999, le conseil d'administration de la SCA a mis sur pied une Commission temporaire sur les ressources médicales afin de déterminier les stratégies qui permettent de faire face à la pénurie d'anesthésiologistes au Canada et qui assurent une planification ultérieure des ressources en anesthésie. En liaison avec les participants nationaux et provinciaux, la Commission discute également du modèle des équipes de soins anesthésiques. La SCA, par l'intermédiaire de sa Commission sur les ressources médicales, espère qu'on saura satisfaire aux deux exigences en matière de soins anesthésiques au Canada.

Ce n'est pas une mince affaire que de réaliser un consensus entre les participants nationaux et provinciaux sur un modèle canadien de service anesthésique. Quand on y sera parvenu, il sera possible de formuler et de valider un profil de compétence national pour les assistants en anesthésie. Le profil servira ensuite de guide à l'élaboration d'un programme d'enseignement pour la formation des assistants en anesthésie selon un programme théorique élaboré par un ou plusieurs Départements universitaires canadiens d'anesthésie.
Les programmes de formation des assistants en anesthésie devront tenir compte de méthodes d'évaluation des connaissances antérieures, puisque les auxiliaires en soins de santé qui vont suivre la formation auront vraisemblablement déjà certaines compétences, acquises auparavant en inhalothérapie, sciences infirmières ou médecine ailleurs dans le monde. L'approbation des programmes de formation dans de nombreuses disciplines connexes de la santé se fait selon la démarche d'accréditation conjointe de l'Association médicale canadienne. ${ }^{7}$ La SCA est membre du comité national d'accréditation de l'Accréditation conjointe et une reconnaissance de ce comité profiterait grandement aux programmes d'éducation des assistants en anesthésie.

La reconnaissance de diplômés de programmes de formation accréditée d'assistant en anesthésie devra se faire. Au Manitoba, un récent amendement au Medical Act (Loi médicale) a créé la possibilité d'accorder une licence aux assistants cliniques, comme les assistants en anesthésie, par le Collège des médecins et chirurgiens. Tous les assistants cliniques reconnus par le Collège des médecins et chirurgiens du Manitoba doivent être supervisés par un médecin. Les assistants cliniques qui répondent avec succès aux exigences du Collège peuvent porter le titre $\mathrm{d}^{\prime}$ ' Assistant clinique diplômé» (ACD).

Dans le but de reconnaître les auxiliaires que sont les assistants en anesthésie dans les institutions de soins de santé, le Conseil d'administration de la SCA a récemment approuvé une nouvelle catégorie de membres pour les assistants en anesthésie. La proposition du Conseil, qui doit être ratifiée par les membres de la SCA, indique l'importance des assistants en anesthésie pour les anesthésiologistes du Canada.

Il y a encore beaucoup à faire avant que le rôle des assistants en anesthésie ne soit défini. Cependant, la possibilité pour les anesthésiologistes canadiens de créer un modèle unique de service d'anesthésie est très stimulante.

\section{References}

1 Compendium of Laws and Regulations. Corporation professionnelle des médecins du Québec. May 1993

2 Final Report of the Task Force on Anaesthesia Assistants. Canadian Anaesthetists' Society. Toronto, June 1995.

3 Proposal for Human Resources Development (HRDC) Funding for a National Task Analysis and a Competency Profile for Anaesthesia Assistants: Submitted by the Canadian Anaethetists' Society, the Canadian Society of Respiratory Therapists and the Operating Room Nurses Association of Canada. January 1997. 
4 Letter from Ms. Bonny Hoyt-Hallett, Chair Federal/Provincial/Territorial Advisory Committee on Health Human Resources to Ms. Cynthia Waugh, Senior Industrial Consultant, Sectoral Partnerships Delivery Division, Human Resources Development Canada. Ottawa, June 1997.

5 Byrick RJ, Craig DB. Consequences of inadequate Canadian physician resource planning (Editorial). Can J Anesth 1999; 46: 913-8.

6 Donen N, King F, Reid D, Blackstock D. Canadian Anesthesia Physician Resources: 1996 and beyond. Can J Anesth 1999; 46: 962-9.

7 Requirements for Accreditation of Educational Programs. Canadian Medical Association. Ottawa: 1999. 